\title{
Partial reversal of the myometrial progesterone 'block' in the non-pregnant ewe in vivo by oestradiol-17 $\beta$
}

\author{
D. G. Porter and S. J. Lye* \\ Pre-Clinical Veterinary Studies, Department of Anatomy, The Medical School, Bristol BS8 1TD, \\ $U . K$.
}

\begin{abstract}
Summary. In ovariectomized non-pregnant ewes myometrial activity, which was suppressed by continued injection of progesterone, showed a significant recovery of both spontaneous activity and oxytocin responsiveness by 12 and by $24 \mathrm{~h}$ after intrauterine administration of oestradiol-17 $\beta$. No such recovery occurred in ewes given vehicle only into the uterus. The oestrogen-induced recovery was lost by $60 \mathrm{~h}$ after treatment. Infusion of PGF- $2 \alpha$ into the uterine lumen instead of oestrogen provided no support for the possibility that the oestrogen-induced recovery was mediated through PGF- $2 \alpha$ secretion. It is suggested that oestradiol may participate in the mechanism of parturition in sheep by accelerating myometrial recovery from the effects of progesterone.
\end{abstract}

\section{Introduction}

Treatment of the ovariectomized non-pregnant ewe with progesterone results in an inhibition of spontaneous myometrial activity and a marked suppression of the uterine response to oxytocic agents (Lye \& Porter, 1978), i.e. a classic progesterone 'block' (Csapo, 1956). As plasma and myometrial progesterone concentrations are high in the ewe during pregnancy (Bassett, Oxborrow, Smith \& Thorburn, 1969; Fylling, 1970; Stabenfeldt, Drost \& Franti, 1972) it seems likely that this hormone is responsible for the marked reduction in mechanical and electrical activity of the myometrium in the pregnant sheep (Hindson \& Ward, 1973;-Mitchell \& Flint, 1978; Lye, 1980; Harding et al., 1982).

Plasma progesterone concentrations decline at term and although there is much variation in the time during which this occurs it is often abrupt and labour may start before progesterone is fully cleared from the circulation (Bassett et al., 1969; Fylling, 1970; Stabenfeldt et al., 1972; Thorburn, Nicol, Bassett, Shutt \& Cox, 1972; Rawlings \& Ward, 1976, 1978). The onset of significant myometrial mechanical activity is only observed some 12-24 h before parturition (Hindson, Schofield, Turner \& Wolff, 1965; Rawlings \& Ward, 1976; Lye, 1980), but thereafter it develops rapidly. On the other hand, Lye \& Porter (1978) found that in the non-pregnant ewe the recovery of the myometrium from the inhibitory effects of progesterone is protracted (about 6 days) despite rapid clearance of progesterone from the peripheral plasma. These apparently divergent findings suggest that the evolution of labour contractions in the sheep is not accomplished solely by the withdrawal of the action of progesterone consequent upon a decline in the secretion of the steroid, but that a mechanism may operate which actively accelerates the recovery of the myometrium.

A possible participant in such a mechanism is oestradiol-17 $\beta$ which, in its unconjugated form,

* Present address: Department of Obstetrics \& Gynaecology, University of Western Ontario, Canada N6A 5A5. 
increases abruptly in the plasma just before parturition in ewes (Challis, 1971). We have investigated the possibility that oestradiol may be capable of interfering with the blocking effect of progesterone on the sheep uterus by observing the changes in intrauterine pressure recordings when ovariectomized ewes receiving chronic progesterone treatment are given intrauterine oestradiol$17 \beta$.

\section{Materials and Methods}

Clun, Clun Cross or Dorset ewes aged 3-7 years with a history of normal fecundity were used. The 16 animals were ovariectomized and equipped with intrauterine pressure balloons and infusion catheters under thiopentone sodium and halothane anaesthesia as described previously (Lye \& Porter, 1978). The ewes were allowed at least 5 days to recover from surgery, during which time they received antibiotic therapy ( $7 \mathrm{ml}$ Strypen: May \& Baker Ltd, Dagenham, U.K.), i.m. daily for 5 days, before intrauterine pressure (IUP) recording began. Once it was apparent that normal pressure cycles had been established (Lye \& Porter, 1978; Text-fig. 1) and the IUP response to a standard dose of $500 \mathrm{mu}$. oxytocin i.v. had been determined, the ewes were allotted to one of the groups detailed below.

Ovariectomized ewes were treated with $50 \mu \mathrm{g}$ oestradiol-17//day s.c. This dose had been found to produce plasma titres of $<30 \mathrm{pg} / \mathrm{ml}$ (D. C. Wathes \& S. J. Lye, unpublished data) and injections were started 5 days after surgery. All ewes except 2 in Group V (see below) received $50 \mathrm{mg}$ progesterone daily throughout the experiment. When oxytocin tests (500 mu. Syntocinon, Sandoz, Feltham, Middlesex, U.K., i.v.) were negative $(\mathrm{t}=0 \mathrm{~h})$ the ewes were treated as follows.

Group $I(\mathrm{~N}=9): 500 \mu \mathrm{g}$ oestradiol-17 3 (in $0.1 \mathrm{ml}$ ethyl alcohol) were injected into the uterine lumen via a catheter and flushed with $0.25 \mathrm{ml}$ sterile saline $(0.9 \% \mathrm{w} / \mathrm{v} \mathrm{NaCl})$. Treatment was repeated at $\mathrm{t}=12 \mathrm{~h}$. Oxytocin tests were performed at 0,12 and $24 \mathrm{~h}$ and at $24-\mathrm{h}$ intervals thereafter. IUP was monitored for at least $30 \mathrm{~min}$ before and after each oxytocin test.

Group $I(\mathrm{~N}=7)$ : the treatment was similar to that of Group I except that $250 \mu \mathrm{g}$ oestradiol-17 $\beta$ were administered intraluminally in $0.25 \mathrm{ml}$ corn oil.

Group III $(\mathrm{N}=4)$ : these ewes were treated as in Group I except that oxytocin tests were replaced by intrauterine infusions of PGF- $2 \alpha, 27 \mu \mathrm{g} / \mathrm{min}$ (Dinoprost; Upjohn Ltd, Crawley, Sussex, U.K.).

Group $I V(\mathrm{~N}=9)$ : the treatment was as for Group I except that intrauterine oestradiol-17 $\beta$ treatments were replaced with vehicle, $0.25 \mathrm{ml}$ corn oil $(\mathrm{N}=5)$ or $0.1 \mathrm{ml}$ ethyl alcohol $(\mathrm{N}=4)$.

Group $V(\mathrm{~N}=6)$ : these ewes received intrauterine infusions of PGF- $2 \alpha$ as follows: (a) 2 ewes were treated with $13 \mu \mathrm{g} \mathrm{PGF-2} \alpha$ (I.C.I., Alderley Edge, Cheshire, U.K.) in $0.013 \mathrm{ml} 10 \%$ ethyl alcohol in saline/min for $\sim 8 \mathrm{~h}$ and (b) 2 ewes received $27 \mu \mathrm{g}$ PGF- $2 \alpha$ in $0.013 \mathrm{ml} 0.9 \%$ benzyl alcohol in saline/min for $6 \mathrm{~h}$. Intrauterine pressure was monitored throughout and the response to oxytocin ( $500 \mathrm{mu}$. i.v.) was recorded before, and at the end of the PGF- $2 \alpha$ infusion. In addition, 2 ewes were given 'maintenance oestradiol-17 $\beta$ ' injections but without progesterone and received intrauterine infusions of $10 \%$ ethyl alcohol in saline (i.e. vehicle for PGF-2 $\alpha$ ) at the rate of 0.013 $\mathrm{ml} / \mathrm{min}$ for 4 and $12 \mathrm{~h}$ respectively. IUP was recorded at regular intervals thereafter.

During these experiments some animals were used in more than one group, and in these cases at least 4 days were allowed to elapse after full recovery from the progesterone treatment of one experimental protocol before the start of the next. Animals were only subjected to further treatments if their 'spontaneous' myometrial activity and responses to oxytocin were normal as defined by Lye \& Porter (1978).

\section{Plasma progesterone measurements}

Blood samples were taken from 6 ewes in each of Groups I and II at 0,12 and $24 \mathrm{~h}$ after the initial intrauterine oestradiol treatment and from 5 ewes in Group IV before and at the end of the 
PGF- $2 \alpha$ infusion. Progesterone titres were measured in all samples by radioimmunoassay. The details of the assay are reported elsewhere (Wathes \& Porter, 1982). The sensitivity was $4 \mathrm{pg} /$ tube and the inter- and intra-assay coefficients of variation were 12.6 and $10.7 \%$ respectively.

\section{Analysis of IUP records}

The records for animals in Groups I- IV were divided into 10-min segments and analysed for frequency and maximum amplitude of IUP cycles during the $30 \mathrm{~min}$ before and the $30 \mathrm{~min}$ after the oxytocin or PGF-2 $\alpha$ administration. An IUP cycle was arbitrarily defined as a change in IUP in which the pressure increased by at least $10 \mathrm{mmHg}$ above resting (i.e. inter-cyclic) pressure and then fell by at least $10 \mathrm{mmHg}$. The resting pressure was also measured at 1, 2, 3, 4, 5, 10, 20 and $30 \mathrm{~min}$ after administration of oxytocin or PGF- $2 \alpha$ and expressed as the incremental change (in $\mathrm{mmHg}$ ) from the mean resting pressure recorded during the preceding $30 \mathrm{~min}$. Data were subjected to an analysis of variance or to a Student's $t$ test (Armitage, 1971) to test for statistical significance. Results are expressed as means \pm standard error of the mean. Unless otherwise stated all times are related to $\mathrm{t}=0 \mathrm{~h}$ as defined above.

The records from Group $\mathrm{V}$ were also analysed for frequency and for maximum amplitude of IUP cycles at $0,2,4,6$, and, when possible, $8 \mathrm{~h}$ after the beginning of the infusions. The response to oxytocin was analysed as described above, before and at the end of the infusion period. No statistical analysis was performed on the data from this group.

\section{Results}

During progesterone treatment all ewes in all groups exhibited a loss of spontaneous uterine activity and responsiveness to oxytocin as previously reported (Lye \& Porter, 1978): the amplitude of IUP cycles declined to $<10 \mathrm{mmHg}$ and almost no uterine mechanical response could be elicited to i.v. injections of oxytocin (Text-fig. 1).

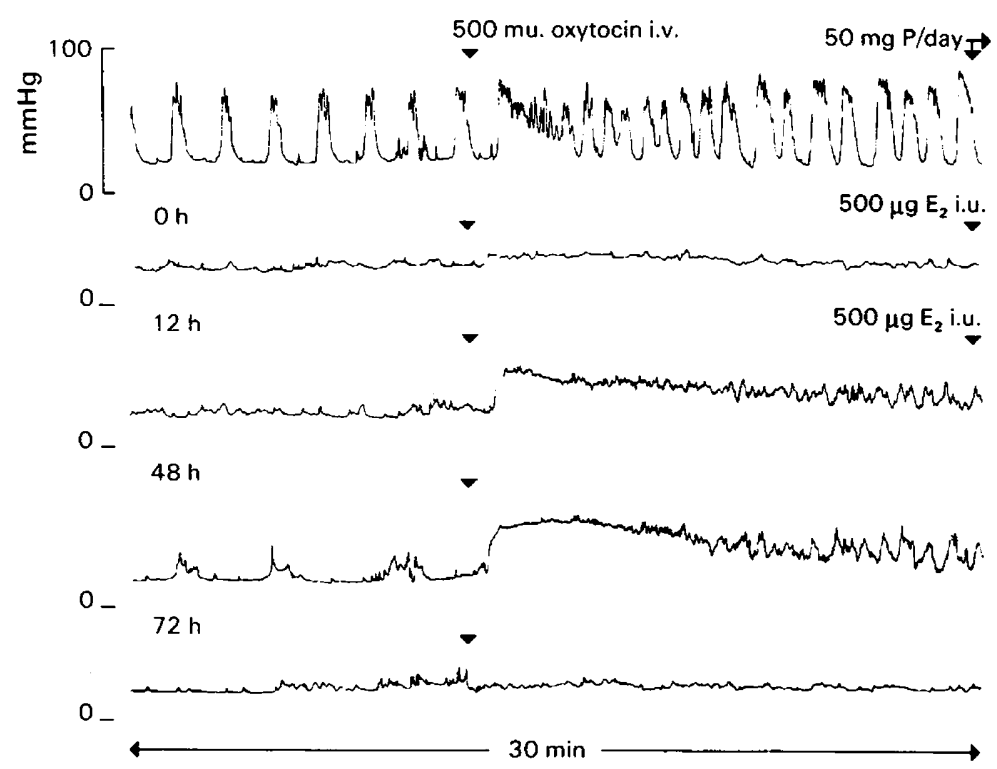

Text-fig. 1. Intrauterine pressure recordings from one uterine horn of an ovariectomized ewe from Group I before and after the establishment of a progesterone 'block' of the myometrium and before and after intrauterine treatment with oestradiol-17 $\beta$. At each time, i.e. before the block and at $0,12,24$ and $72 \mathrm{~h}$ after oestradiol, the response to $500 \mathrm{mu}$. oxytocin i.v. is shown $(\boldsymbol{\nabla})$. 
Group I. By $12 \mathrm{~h}$ after the first administration of $500 \mu \mathrm{g}$ oestradiol- $17 \beta$ to each uterine horn spontaneous IUP cycles had begun to reappear and by $24 \mathrm{~h}$ showed a significant increase in frequency over pre-treatment values $(P<0.01)$. In addition, the uterus showed a marked increase in responsiveness to oxytocin injections at $12 \mathrm{~h}$ (Text-fig. 1) in the form of a substantial and prolonged elevation of resting pressure which, as it declined, was succeeded by IUP cycles that occurred at an increased frequency and amplitude (Table 1). Thus the increment in resting pressure in response to oxytocin had increased significantly by $12 \mathrm{~h}(P<0.001)$ and was even greater at $24 \mathrm{~h}$. Also, the frequency of IUP cycles after oxytocin treatment was significantly greater at 12 and $24 \mathrm{~h}$ than at $0 \mathrm{~h}(P<0.001)$. Text-figures 2 and 3 summarize the effect of oestrogen on uterine responsiveness in this group. With continued progesterone treatment the enhanced spontaneous activity and the responsiveness to oxytocin were lost by $72 \mathrm{~h}$ (Text-fig. 1).

Table 1. Mean \pm s.e.m. maximum amplitude of IUP cycles in ewes treated with progesterone and given intrauterine injections of $500 \mu \mathrm{g}$ oestradiol- $17 \beta$ at 0 and $12 \mathrm{~h}$

\begin{tabular}{ccc}
\hline \multirow{2}{*}{$\begin{array}{c}\text { Time } \\
\text { (h) }\end{array}$} & \multicolumn{2}{c}{ Amplitude of IUP cycles $(\mathrm{mmHg})$} \\
\cline { 2 - 3 } & Spontaneous & Oxytocin-induced \\
\hline 0 & $11 \cdot 9 \pm 0.7^{*}$ & $15 \cdot 5 \pm 1 \cdot 9$ \\
12 & $13 \cdot 3 \pm 0 \cdot 7^{\dagger}$ & $24.0 \pm 1.0 \dagger$ \\
24 & $16 \cdot 1 \pm 0.9^{*} \ddagger$ & $33.4 \pm 1.2 \ddagger$ \\
\hline
\end{tabular}

$* \ddagger$ Values significantly different, $P<0.001$.

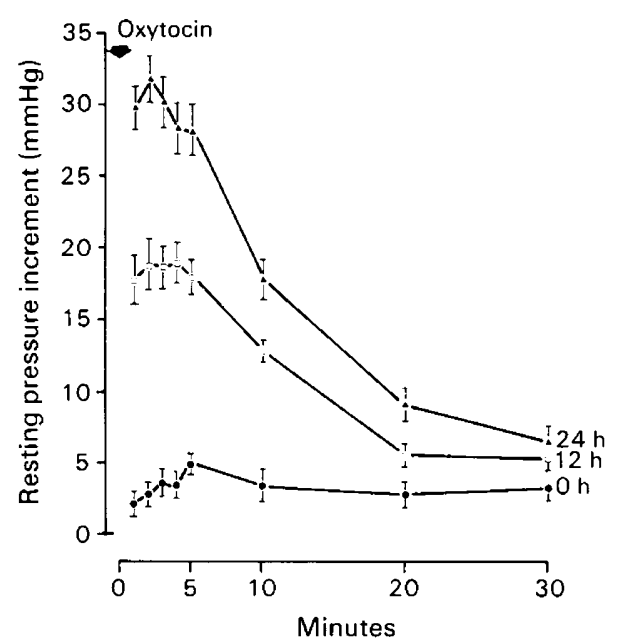

Text-fig. 2. Graph showing mean increase ( \pm s.e.m.) in resting pressure during the 30 -min period after administration of oxytocin $(500 \mathrm{mu}$. i.v. $)$ at 0,12 and $24 \mathrm{~h}$ after the initial intrauterine treatment with oestradiol-17 $\beta(500 \mu \mathrm{g}$ to each horn) in ovariectomized ewes receiving daily progesterone injections $(\mathrm{N}=9)$.

Group II. Despite the reduced dose of $250 \mu \mathrm{g}$ oestradiol-17 $\beta$ instilled in each uterine horn there was nevertheless a marked increase in spontaneous uterine activity and in the responsiveness to oxytocin ( $500 \mathrm{mu}$. i.v.) in the ewes in this group similar to that observed in Group I. Following intrauterine oestrogen treatment the frequency of spontaneous IUP cycles increased from 0.8 cycles $/ 10 \mathrm{~min}$ at $0 \mathrm{~h}$ to 3.7 cycles $/ 10 \mathrm{~min}$ at $24 \mathrm{~h}(P<0.001)$. The mean frequency of IUP cycles (over $30 \mathrm{~min}$ ) induced by oxytocin treatment also increased significantly after intrauterine oestrogen treatment $(2.1$ cycles $/ 10 \mathrm{~min}$ at $0 \mathrm{~h}$ to 9.0 cycles $/ 10 \mathrm{~min}$ at $24 \mathrm{~h}: P<0.001)$, as did the in-

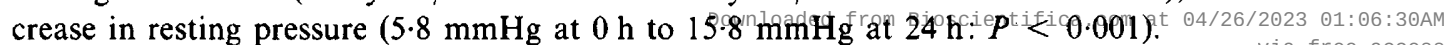




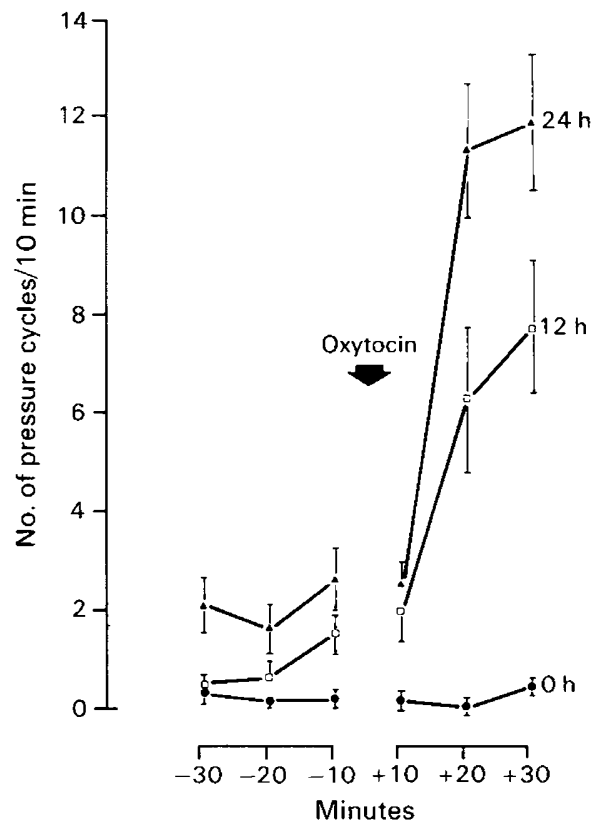

Text-fig. 3. Graph of frequency of intrauterine pressure cycles $(>10 \mathrm{mmHg}$ ) for $30 \mathrm{~min}$ before until $30 \mathrm{~min}$ after oxytocin injection $(500 \mathrm{mu}$. i.v.) at 0,12 and $24 \mathrm{~h}$ after the initial intrauterine treatment with oestradiol-17 $(500 \mu \mathrm{g}$ to each horn).

Group III. The IUP response to the intrauterine infusion of PGF- $2 \alpha$ during progesterone treatment is shown in Text-fig. 4. Although no significant difference was detected at $12 \mathrm{~h}$, by $24 \mathrm{~h}$ the mean frequency of IUP cycles was significantly increased in response to PGF-2 $\alpha$ infusion $(P<$ $0 \cdot 05$ ). Mean maximum amplitude and resting pressure showed considerable variation and the changes were not statistically significant.
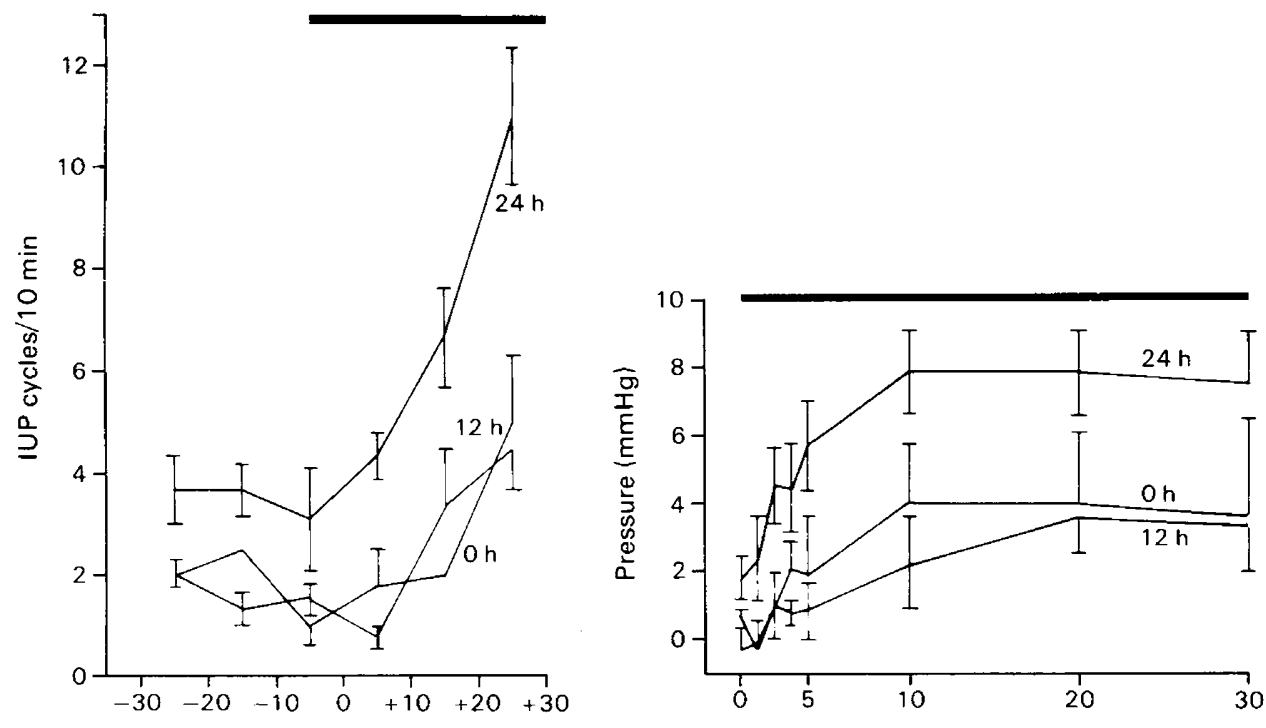

Minutes

Text-fig. 4. The effect of intrauterine infusion of PGF- $2 \alpha(27 \mu \mathrm{g} / \mathrm{min}$ black bars $)$ on mean \pm s.e.m. frequency and maximum amplitude of pressure cycles in uterine horns of ovariectomized ewes maintained on oestrogen and progesterone, at 0,12 and $24 \mathrm{~h}$ after intrauterine treatment with oestradiol-17 $\beta$ (500 $\mu \mathrm{g}$ to each horn). 
Group IV. There was no significant difference between the sub-groups treated with ethyl alcohol or corn oil in frequency of IUP cycles or increase in resting pressure, and these data have therefore been pooled. There was no increase in spontaneous myometrial activity or responsiveness to oxytocin in the progesterone-treated ewes receiving vehicle injections, throughout the $24 \mathrm{~h}$ of the experiment. There was a slight elevation of the mean resting pressure $(6-9 \mathrm{mmHg})$ during the 30 min after oxytocin injections at each of the times tested.

Group $V$. The results from animals in sub-groups (a) and (b) appeared similar and are considered together. Although the infusion of PGF- $2 \alpha$ caused an increase in frequency during the 6-h treatment, from $0.7 \pm 0.4$ IUP cycles $/ 10 \mathrm{~min}$ to $3.3 \pm 1.4$ at $2 \mathrm{~h}, 4.0 \pm 1.4$ at $4 \mathrm{~h}$, and $5.3 \pm 1.3$ at $6 \mathrm{~h}$, no significant differences were observed in the frequency or resting pressure responses to $500 \mathrm{mu}$. oxytocin i.v. before or after the PGF- $2 \alpha$ infusion. Plasma progesterone titres in the ewes in this group were $3.0 \pm 0.29 \mathrm{ng} / \mathrm{ml}$ before and $2.9 \pm 0.022 \mathrm{ng} / \mathrm{ml}$ at the end of the PGF-2 $\alpha$ infusion.

Intraluminal infusion of $10 \%$ ethyl alcohol in saline in 2 ovariectomized ewes receiving 'maintenance oestrogen' only had no effect on spontaneous IUP cycles, or on the uterine responsiveness to oxytocin (500 mu. i.v.).

\section{Plasma progesterone titres}

Progesterone concentrations in blood samples $(n=6)$ taken at 0,12 and $24 \mathrm{~h}$ after treatment were $2.0 \pm 0.3,2.2 \pm 0.3$ and $2 \cdot 1 \pm 0.2 \mathrm{ng} / \mathrm{ml}$ in ewes receiving intrauterine oestrogen (Group I) and $1.9 \pm 0.2,2.0 \pm 0.2$ and $1.8 \pm 0.3 \mathrm{ng} / \mathrm{ml}$ respectively in ewes receiving intrauterine injections of vehicle only (Group IV). None of these values differed significantly.

\section{Discussion}

These results demonstrate that the fully established progesterone 'block' of the ovine myometrium can be partly but significantly overcome by oestradiol-17 $\beta$. Thus in ewes receiving intraluminal injections of 250 or $500 \mu \mathrm{g}$ oestradiol-17 7 there was a significant recovery of spontaneous IUP cycles as well as the resting pressure, frequency and mean maximum amplitude responses to oxytocin, by $24 \mathrm{~h}$, and in many cases by $12 \mathrm{~h}$, after treatment compared with control ewes treated with vehicle only. This recovery was observed despite the continued administration of progesterone.

It might be objected that the dose of oestradiol was 'pharmacological' but, in normal pregnancy (which this experiment was designed to simulate) the source of oestradiol at term is the placenta (Fevre, 1967; Bedford, Challis, Harrison \& Heap, 1972) and in order to produce peripheral plasma titres of oestradiol exceeding $100 \mathrm{pg} / \mathrm{ml}$ it must be synthesizing considerable quantities of this steroid. Indeed the data of Challis, Harrison \& Heap (1973) suggest that production rate during labour may amount to more than $1.5 \mathrm{mg} / 24 \mathrm{~h}$ of oestradiol- $17 \beta$ plus a probably greater quantity of oestrone. It is likely that this would reach the myometrium in high concentrations, since Porter (1968) showed that another steroid (progesterone), when delivered intraluminally, was able to affect the myometrium by a local route.

The lack of significant change in plasma progesterone titres throughout the experiments confirms that the changes in myometrial behaviour cannot be attributed to a withdrawal of progesterone. A similar increase in myometrial activity and responsiveness without a fall in plasma progesterone titres was reported in pregnant ewes given stilboestrol (Liggins, Grieves, Kendall \& Knox, 1972). Other workers have reported a stimulatory action of stilboestrol during late pregnancy in ewes (Hindson, Schofield \& Turner, 1967; Cahill, Knee \& Lawson, 1976). However, because of the complex nature of the hormonal environment in late pregnancy it is not certain from these reports that oestradiol acted directly on the myometrium. The present experiments support such an action. 
The precise mechanism by which oestradiol antagonizes the action of progesterone is uncertain. The fact that the effects of oestrogen were greater at 24 than at $12 \mathrm{~h}$ is consistent with a relatively long latency period and suggests that a protein synthetic step may be involved as in other actions of the steroid (Jensen \& DeSombre, 1972; O’Malley \& Means, 1974). The claim by Liggins et al. (1972) that the myometrial threshold for oxytocin in pregnant ewes was significantly reduced by the intraaortic infusion of PGF- $2 \alpha$ suggests that oestradiol may exert its antiprogesterone effects by causing the synthesis and release of this agent. However, our experiments in which progesterone-treated ewes were infused with PGF-2 $\alpha$ for up to $8 \mathrm{~h}$ failed to reveal a significant change in oxytocin responsiveness and therefore cast doubt on this hypothesis.

Oestrogen has been shown to have a number of actions on the uterus which could contribute to the effects reported here, such as increasing the population of oxytocin receptors (Alexandrova $\&$ Soloff, 1980) and the number of gap junctions between uterine smooth muscle cells (Garfield, Rabideau, Challis \& Daniel, 1979; Wathes \& Porter, 1982), stimulation of actin and myosin formation in the myometrium (Caspo \& Corner, 1952) and augmenting myometrial blood flow (Rosenfeld, Morris, Battaglia, Makowski \& Meschia, 1976). The relative contribution of these factors, or of others as yet unknown, cannot be estimated from these experiments.

These results therefore provide justification for postulating that oestradiol, which is markedly elevated in the plasma pre partum, participates in the initiation of normal parturition by accelerating the recovery of the uterus from the effects of progesterone so that recovery is faster than could occur merely as a result of waning placental output of this steroid. Whether or not such a mechanism is essential for labour is uncertain because Kendall et al. (1977) have reported that parturition occurred without an increase in maternal oestrogen titres when hypophysectomized lambs were infused in utero with ACTH. However, Ricketts, Sheldrick, Lindsay \& Flint (1980) were unable to confirm this finding. Rawlings, Pant \& Ward (1978) found that ewes passively immunized against oestrogens were able to deliver normally, but this study does not conclusively exclude the participation of oestrogens in normal ovine parturition because, as the authors themselves point out, a locally operating mechanism involving oestrogen would not have been excluded.

We thank Mrs Wendy Sansum for skilled technical assistance; Dr D. C. Wathes for the progesterone measurements; Mrs S. Somers for typing the manuscript; Dr B. Furr, ICI Ltd, Macclesfield, Cheshire, for the gift of PGF-2 $\alpha$; and the A.R.C. for financial support.

\section{References}

Alexandrova, M. \& Soloff, M.S. (1980) Oxytocin receptors and parturition. I. Control of oxytocin receptor concentration in the rat myometrium at term. Endocrinology 106, 730-735.

Armitage, P. (1971) Statistical influence. Comparison of two means. In Statistical Methods in Medical Research, pp. 99-147. Ed. P. Armitage. Blackwell Scientific Publications, Oxford.

Bassett, J.M., Oxborrow, T.J., Smith, I.D. \& Thorburn, G.D. (1969) The concentrations of progesterone in the peripheral plasma of the pregnant ewe. $J$. Endocr. 45, 449-457.

Bedford, C.A., Challis, J.R.G., Harrison, F.A. \& Heap, R.B. (1972) The role of oestrogens and progesterone in the onset of parturition in various species. $J$. Reprod. Fert., Suppl. 16, 1-23.

Cahill, L.P., Knee, B.W. \& Lawson, R.A.S. (1976) Induction of parturition in ewes with a single dose of oestradiol benzoate. J. Reprod. Fert. 46, 528-529.

Challis, J.R.G. (1971) Sharp increase in free circulating oestrogen immediately before parturition in sheep. Nature, Lond. 299, 208.
Challis, J.R.G., Harrison, F.A. \& Heap, R.B. (1973) The kinetics of oestrogen metabolism in the pregnant sheep. In The Endocrinology of Pregnancy and Parturition: Experimental Studies in the Sheep, pp. 7382. Ed. C. G. Pierrepoint. Alpha Omega Alpha, Cardiff.

Csapo, A.I. (1956) Progesterone block. Am. J. Anat. 98, 273-291.

Csapo, A.I. \& Corner, G.W. (1952) The antagonistic effects of oestrogen and progesterone on the staircase phenomenon in uterine muscle. Endocrinology 51, $378-385$.

Fevre, J. (1967) Oestrogènes urinaires chez la brebis gestante ovariectomisée. Annls Biol. anim. Biochim. Biophys. 7, 29-32.

Fylling, P. (1970) The effect of pregnancy, ovariectomy and parturition on plasma progesterone levels in sheep. Acta endocr., Copenh. 65, 273-283.

Garfield, R.E., Rabideau, S., Challis, J.R.G. \& Daniel, E.E. (1979) Hormonal control of gap junction formation in sheep myometrium during parturition. Biol. Reprod. 21, 999-1007. 
Harding, R., Poore, E.R., Bailey, A., Thorburn, G.D., Jansen, C.A.M. \& Nathanielsz, P.W. (1982) Electromyographic activity of the nonpregnant and pregnant sheep uterus. Am. J. Obstet. Gynec. 142, 448-457.

Hindson, J.C. \& Ward, W.R. (1973) Myometrial studies in pregnant sheep. In The Endocrinology of Pregnancy and Parturition: Experimental Studies of the Sheep, pp. 153-162. Ed. C. G. Pierrepoint. Alpha Omega Alpha, Cardiff.

Hindson, J.C., Schofield, B.M., Turner, C.B. \& Wolf, H.S. (1965) Parturition in the sheep. J. Physiol., Lond. 181, 560-567.

Hindson, J.C., Schofield, B.M. \& Turner, C.B. (1967) The effect of a single dose of stilboestrol on cervical dilatation in pregnant sheep. Res. Vet. Sci. 8, 353360 .

Jensen, E.V. \& DeSombre, E.R. (1972) Mechanism of action of the female sex hormones. Ann. Rex. Biochem. 41, 203-230.

Kendall, J.Z., Challis, J.R.G., Hart, I.C., Jones, C.T., Mitchell, M.D., Ritchie, J.W.K., Robinson, J.S. \& Thorburn, G.D. (1977) Steroid and prostaglandin concentrations in the plasma of pregnant ewes during infusion of ACTH or dexamethasone to intact or hypophysectomised fetuses. $J$. Endocr. 75, 59-71.

Liggins, G.C., Grieves, S.A., Kendall, J.Z. \& Knox, B.S. (1972) The physiological role of progesterone, oestradiol-17 $\beta$ and prostaglandin $F_{2 \alpha}$ in the control of ovine parturition. J. Reprod. Fert., Suppl. 16, 85-104.

Lye, S.J. (1980) The hormonal control of myometrial activity in the sheep and rat. Ph.D. thesis, University of Bristol.

Lye, S.J. \& Porter, D.G. (1978) Demonstration that progesterone 'blocks' uterine activity in the ewe in vivo by a direct action on the myometrium. J. Reprod. Fert. 52, 87-94.

Mitchell, M.D. \& Flint, A.P.F. (1978) Use of meclofenamic acid to investigate the role of prostaglandin biosynthesis during induced parturition in sheep. $J$. Endocr. 76, 101-109.
O'Malley, B.W. \& Means, A.R. (1974) Female steroid hormones and target cell nuclei. Science, N.Y. 183, $610-620$.

Porter, D.G. (1968) The local effect of intrauterine progesterone treatment on myometrial activity in rabbits. J. Reprod. Fert. 15, 437-445.

Rawlings, N.C. \& Ward, W.R. (1976) Changes in steroid hormones in the plasma and myometrium, and uterine activity in ewes during late pregnancy and parturition. J. Reprod. Fert. 48, 355-360.

Rawlings, N.C. \& Ward, W.R. (1978) Correlations of maternal and fetal endocrine events with uterine pressure changes around parturition in the ewe. $J$. Reprod. Fert. 54, 1-8.

Rawlings, N.C., Pant, H.C. \& Ward, W.R. (1978) The effect of passive immunization against oestrogens on the onset of parturition in the ewe. J. Reprod. Fert. 54, 363-367.

Ricketts, A.P., Sheldrick, E.L., Lindsay, K.S. \& Flint, A.P.F. (1980) Induction of labour in sheep after fetal hypophysectomy: an investigation of the possible involvement of a fetal pituitary secretion in the activation of placental enzymes by fetal cortisol. Placenta 1, 287-297.

Rosenfeld, C.R., Morris, F.H., Battaglia, F.C., Makowski, E.L. \& Meschia, G. (1976) Effect of estradiol-17$\beta$ on blood flow to reproductive and nonreproductive tissues in pregnant ewes. Am. J. Obstet. Gynec. 124, 618-629.

Stabenfeldt, G.H., Drost, M. \& Franti, C.E. (1972) Peripheral plasma progesterone levels in the ewe during pregnancy and parturition. Endocrinology 90 , 144-150.

Thorburn, G.D., Nicol, D.H., Bassett, J.M., Shutt, D.A. \& Cox, R.I. (1972) Parturition in the goat and sheep: changes in corticosteroids, progesterone, oestrogens and prostaglandin $\mathrm{F}_{2 \alpha} . J$. Reprod. Fert., Suppl. 16,6184.

Wathes, D.C. \& Porter, D.G. (1982) The effect of uterine distension and oestrogen treatment on gap junction formation in the myometrium of the rat. $J$. Reprod. Fert. 65, 497-505. 